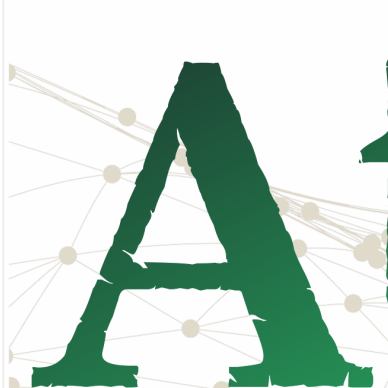

ISSN n² 2526-8031

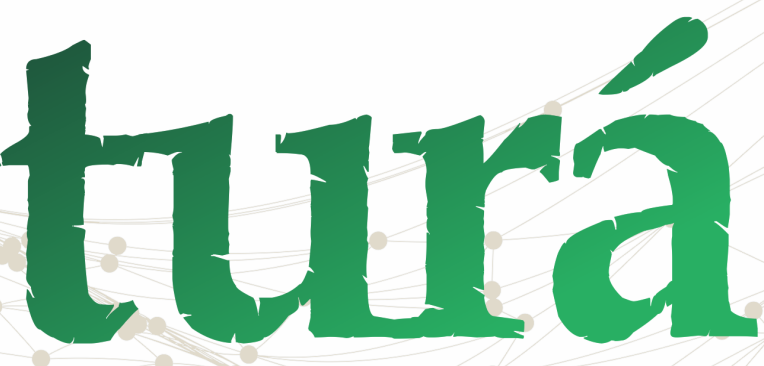

Vol. 3, n. 3, Setembro-Dezembro. 2019

\title{
PASSADO E PRESENTE NA BELÉM CONTEMPORÂNEA: A configuração das narrativas cotidianas de assombração dos palacetes antigos no es- paço urbano
}

PAST AND PRESENT IN CONTEMPORARY BELÉM: The configuration of everyday narratives of haunting ancient palaces in urban space

PASADO Y PRESENTE EN BELÉM CONTEMPORÁNEO: La configuración de narraciones cotidianas de inquietantes palacios antiguos en el espacio urbano

\section{Lídia Karoline Rodarte ${ }^{1}$ \\ Alda Cristina Silva da Costa ${ }^{2}$ \\ Jússia Carvalho da Silva Ventura ${ }^{3}$ \\ Raul da Silva Ventura Neto ${ }^{4}$}

\section{RESUMO}

Este artigo busca compreender como as narrativas de assombração são configuradas, cotidianamente, no espaço urbano de Belém. Nossas reflexões partem da tessitura da intriga ricoeuriana e da lógica do falatório heideggeriano, em que as histórias criam memórias comuns entre

\footnotetext{
${ }^{1}$ Doutoranda do Curso de Pós-Graduação em Comunicação, Cultura e Amazônia da Universidade Federal do Pará (PPGCom/UFPA), Mestre em Comunicação pelo PPGCom/UFPA. Integrante do Grupo de Pesquisa Narrativas Contemporâneas na Amazônia (Narramazônia). E-mail: E-mail: lidiakarolina@gmail.com.

2 Docente da Faculdade de Comunicação e do Programa de Pós-Graduação Comunicação, Cultura e Amazônia PPGCom/Universidade Federal do Pará; coordena os projetos de pesquisa Narrativas Contemporâneas na Amazônia Paraense e Mídia e Violência: percepções e representações na Amazônia. E-mail: E-mail: aldacristinacosta@gmail.com.

${ }^{3}$ Doutoranda do Curso de Pós-Graduação em Sociologia e Antropologia da Universidade Federal do Pará, Mestra em Comunicação pelo Programa de Pós-Graduação Comunicação, Cultura e Amazônia da UFPA, professora da Faculdade de Comunicação da UFPA. Integrante dos Grupos de Pesquisa Interações e Tecnologias na AmazôniaITA (CNPQ) e Comunicação, Consumo e Identidade - CONSIA. E-mail: jussiac@gmail.com.

${ }^{4}$ Docente da Faculdade e do Programa de Pós Graduação em Arquitetura e Urbanismo da UFPA. Mestre em Arquitetura e Urbanismo pela UFPA e doutor em Desenvolvimento Econômico pela Universidade de Campinas. E-mail: netoventuraraul@gmail.com.
} 


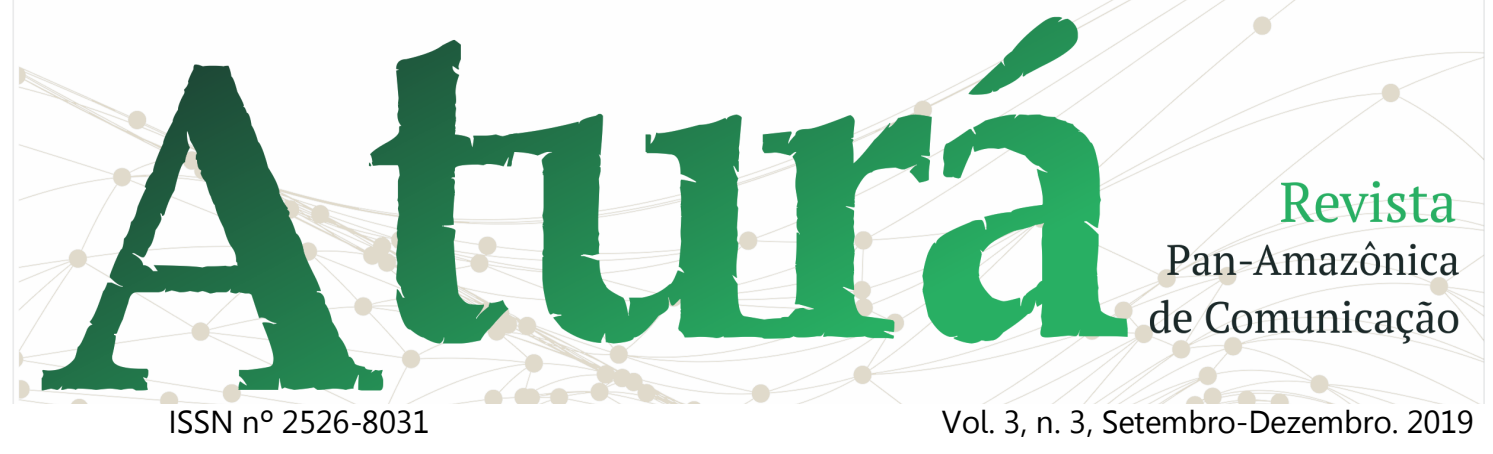

as pessoas, sobrevivem ao tempo, às mudanças e às dinâmicas, mesmo sem possuírem fontes históricas que the confirmem sua veracidade ou conhecimentos prévios. Ou seja, são impregnadas de um saber intuitivo, disponíveis a todos, sendo ao mesmo tempo saber e não-saber, que se repete e é passado adiante. Toma-se como escopo de análise duas narrativas que circulam na internet sobre os antigos palacetes de Belém do Pará: Bolonha e Bibi Costa, construídos em períodos faustos da economia paraense. Nessas histórias, passado/presente demarcam sentidos ou discursos já previamente estabelecidos ou compreendidos. Assim, as narrativas de assombração são compreendidas/interpretadas numa lógica do imaginário sobre o espaço.

PALAVRAS-CHAVE: assombração; narrativas; espaço urbano; Palacete Bibi Costa; Palacete Bolonha.

\section{ABSTRACT}

This article seeks to understand how the haunting narratives are configured, daily, in the urban space of Belém. Our reflections are based on the weavering of the ricoeurian intrigue and the logic of Heideggerian 'idle talk', in which stories create common memories among people, survive time, changes and dynamics, even without historical sources that confirm their truth or previous knowledge. In other words, they are imbued with an intuitive knowledge, available to all, being at the same time knowing and not knowing, which is repeated and passed on. It has been taken as scope of analysis two narratives that circulate on the internet about the old palaces of Belém do Pará: Bologna and Bibi Costa, built in faust periods of the state's economy. In these stories, past / present demarcate meanings or discourses previously established or understood. Thus, the haunting narratives are understood / interpreted in a logic of the imaginary over space.

KEYWORDS: haunting; narratives; urban space; Bibi Costa Palace; Bologna Palace.

\section{RESUMEN}

Este artículo busca comprender cómo las narrativas embrujadas se configuran, diariamente, en el espacio urbano de Belém. Nuestras reflexiones se basan en el tejido de intriga de Ricoeur y la lógica de la habladuria de Heidegger, en la que las historias crean recuerdos comunes entre las personas, sobreviven al tiempo, a cambios y las dinámicas, incluso sin tener fuentes históricas que confirmen su verdad o conocimiento previo. Es decir, están imbuidos de un conocimiento 


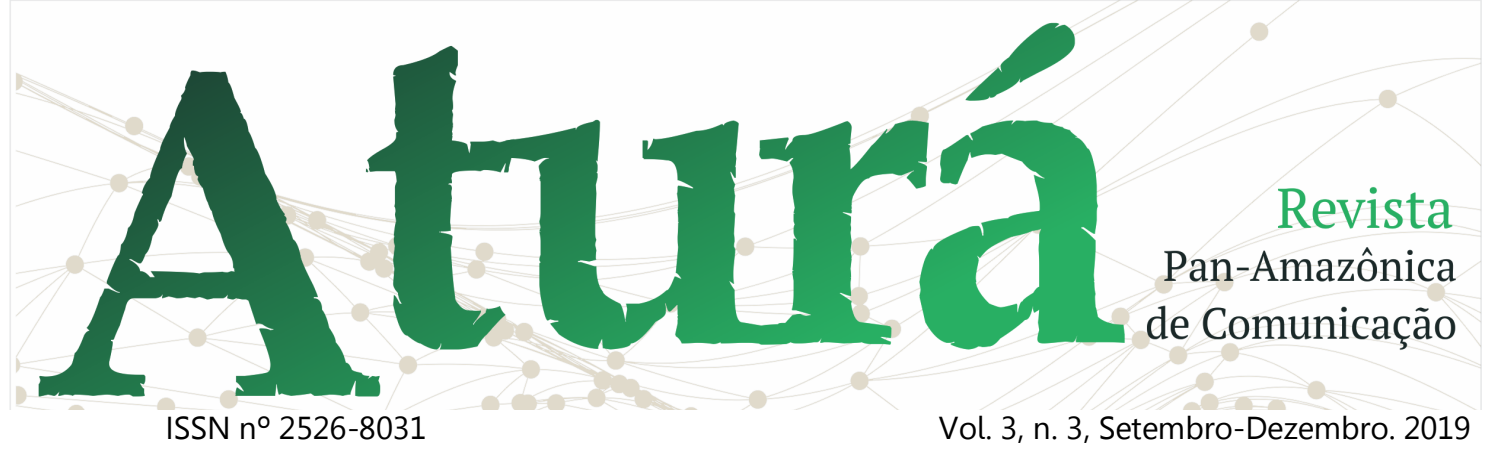

intuitivo, disponible para todos, al mismo tiempo que saben y no saben, que se repite y se transmite. Toma como ámbito de análisis dos narrativas que circulan en Internet sobre los antiguos palacios de Belém do Pará: Bolonia y Bibi Costa, construidas en períodos faustos de la economía local. En estas historias, el pasado / presente demarcan significados o discursos ya establecidos o entendidos previamente. Así, las narrativas inquietantes se entienden / interpretan en una lógica de lo imaginario sobre el espacio.

PALABRAS CLAVE: embrujada; narrativas espacio urbano; Palacio Bibi Costa; Palacio de Bolonia

Recebido em: 22.06.2019. Aceito em: 09.08.2019. Publicado em: 01.09.2019. 


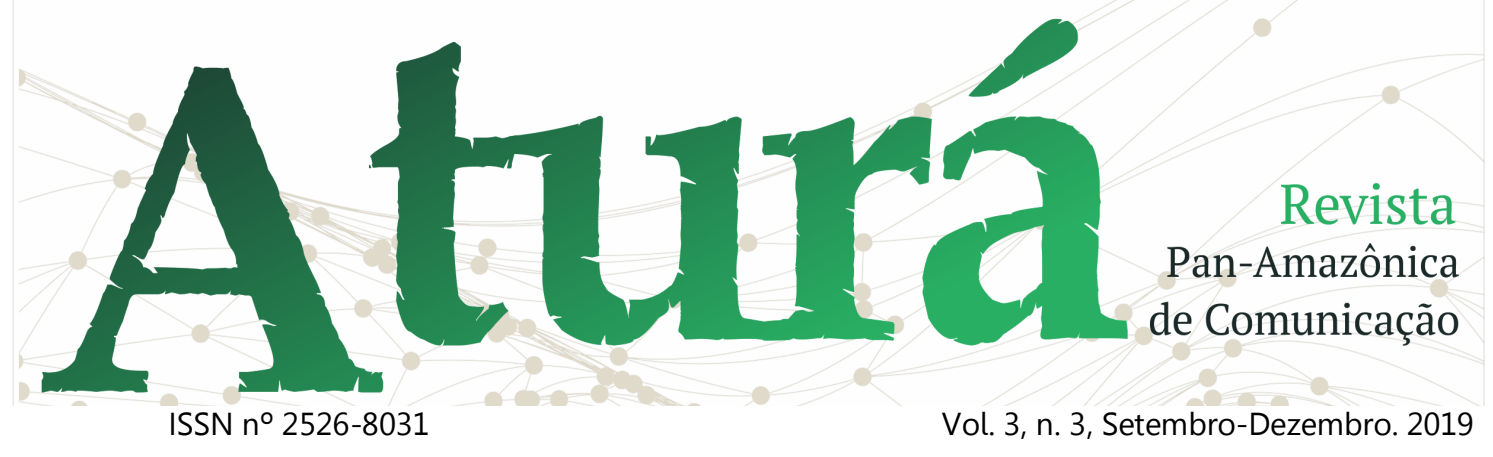

Imaginários do espaço urbano

Neste artigo, compreendemos o espaço urbano pelo sentido de relações e vida, nas quais se inscrevem as sociabilidades, produções culturais e sociais, assim como as diferentes apropriações. Pensamos para além do entendimento físico do espaço, mas também sobre o imaginário que nele habita ou as "cartografias mentais e emocionais que variam segundo os modos pessoais de experimentar as interações sociais" (CANCLINI, 2008, p.15), pois ambos são amalgamas nas inter-relações socioculturais, em que o "urbano se configura como um modo de vida, uma sensibilidade e uma cultura, vivenciadas como imaginário" (HARVEY, 1980, p. 265). É um urbano configurado em tensão entre uma definição que diz o que é e outra que acreditamos ou gostaríamos que fosse.

Entre a Cidade e o Urbano há uma diferenciação, pois com a primeira se identifica a realidade imediata e com o segundo a realidade social, uma vez que o "urbano não é uma alma, um espírito, uma entidade filosófica, mas um composto de relações a serem concebidas e construídas" (LEFEBVRE, 1991, p. 49). Para o autor, devemos pensar a Cidade como texto escrito e à realidade Urbana como conjunto de signos em que procuramos os significados, ou seja, realidades prático-sensíveis que realizam o significante no espaço.
Assim, tecemos a escrita deste artigo, pensando no imaginário inscrito sobre os prédios antigos que compõem a arquitetura urbana da cidade de Belém, com o objetivo de compreender como as narrativas de assombração são configuradas, cotidianamente, sobre esses espaços. Como escopo de análise, selecionamos dois vídeos, abrigados no Youtube, canal "Senhora Morte", série Belém Assombrada, que narram a história de dois palacetes de Belém - Bibi Costa e Bolonha. O canal, criado em agosto de 2015, possui 22.118 inscritos $^{5}$, segundo autodescrição é um lugar com histórias macabras e locais assombrados, para quem gosta de histórias de terror $^{6}$.

Analisamos as histórias de 'visagem ${ }^{71}$ como uma narrativa configurada pela lógica do falatório heideggeriano, que se orienta menos pela veracidade e pelo sentido da história em si, do que para a interação e os sentidos produzidos no mundo cotidiano, na criação de memórias comuns entre as pessoas.

\section{Memória coletiva e imaginário cultural da cidade de Belém: ressignificando espaços}

\footnotetext{
${ }^{5}$ Até o dia 11 de agosto de 2019.

${ }^{6}$ Descrição do Canal "Senhora Morte": Disponível em: <https://www.youtube.com/channel/UCGIGwyh AiRIYgpG6K_zkMng/about>. Acesso em: 13 ju. 2019. ${ }^{7}$ Visagem é um termo comumente utilizado no Pará com a finalidade de significar algo sobrenatural. Ou seja, aquelas pessoas que não pertencem mais a esse mundo.
} 


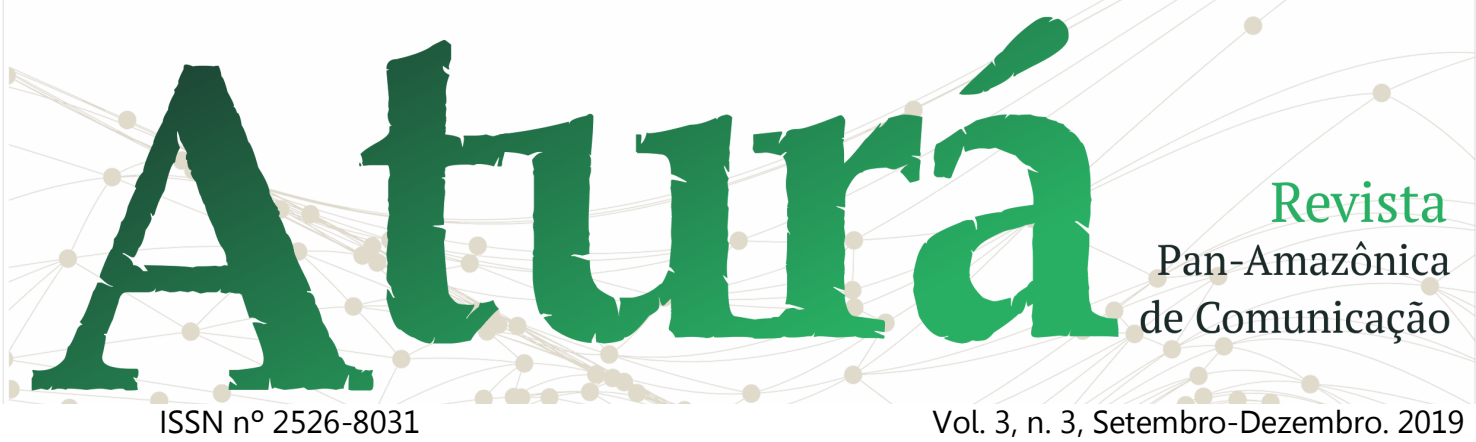

Nosso olhar é sobre a capital do Pará, núcleo urbano primaz da rede urbana amazônica até meados dos anos de 1960 (CORRÊA, 1987), em que Belém é narrada a partir das transformações vivenciadas nos espaços de moradia da elite local. Das casas-grandes e sobrados coloniais, passando por palacetes ecléticos, residências modernistas e até as contemporâneas coberturas de multipavimentos. As transformações morfológicas das residências da elite belenense retratam características típicas da dinâmica de acumulação da economia regional, em que imóveis simbolizam prestígio e riqueza monetária.

Em Belém, o interesse na construção de espaços residenciais representando formas de investimento pessoal e familiar coincidiu com o aquecimento da demanda e do preço no mercado externo do látex da seringueira, período em que a renda interna regional aumentou em quase sete vezes, entre 1870 e 1910, impulsionando a estruturação de um poderoso mercado de terras e imóveis na cidade (WEINSTEIN, 1993).

A ilusão do fausto proporcionado pela riqueza gerada com a exportação da borracha, e que atraiu uma leva de imigrantes nordestinos para o trabalho nos seringais (FURTADO, 2007), encontrava lastro nas reformas urbanas higienistas realizadas em Belém, durante as últimas décadas do século XIX e início do XX, que pretendiam trans-

formá-la em uma Paris do trópico úmido (SARGES, 2000).

Assim como outras cidades do país à época, o palacete tornava-se base de constituição morfológica dos novos bairros de Belém, substituindo muitas vezes os sobrados ou antigas áreas rurais, popularmente conhecidas como rocinhas, articulados ao projeto de reforma urbana da gestão de Antônio Lemos (1897-1911). Essa tipologia burguesa de morar surge na Belém bellepoqueana como principal espaço das famílias da elite paraense, passando com isso a ter nome próprio associados à família proprietária. Eram edificações cujo partido arquitetônico abusava dos ornamentos, dos materiais importados e da especialização funcional do ambiente, elementos que denotavam a estratificação social do morador. Os palacetes rapidamente tornaram-se marco visual das avenidas urbanizadas durante a gestão Lemista e viraram referência de requinte e modernidade para as camadas médias e menos afortunadas (SOARES, 2008).

A ideia de um pequeno palácio - palacete - respondia diretamente ao projeto de modernização de Belém, pois ratificava um novo estilo de morar inspirado na burguesia urbana europeia e nos preceitos da cidade pós-liberal (BENÉVOLO, 2005), como forma hegemônica de habitar. Nesse contexto, a arquitetura residencial passou a ser uma das linguagens de consolidação de uma identidade social diferenciada entre 


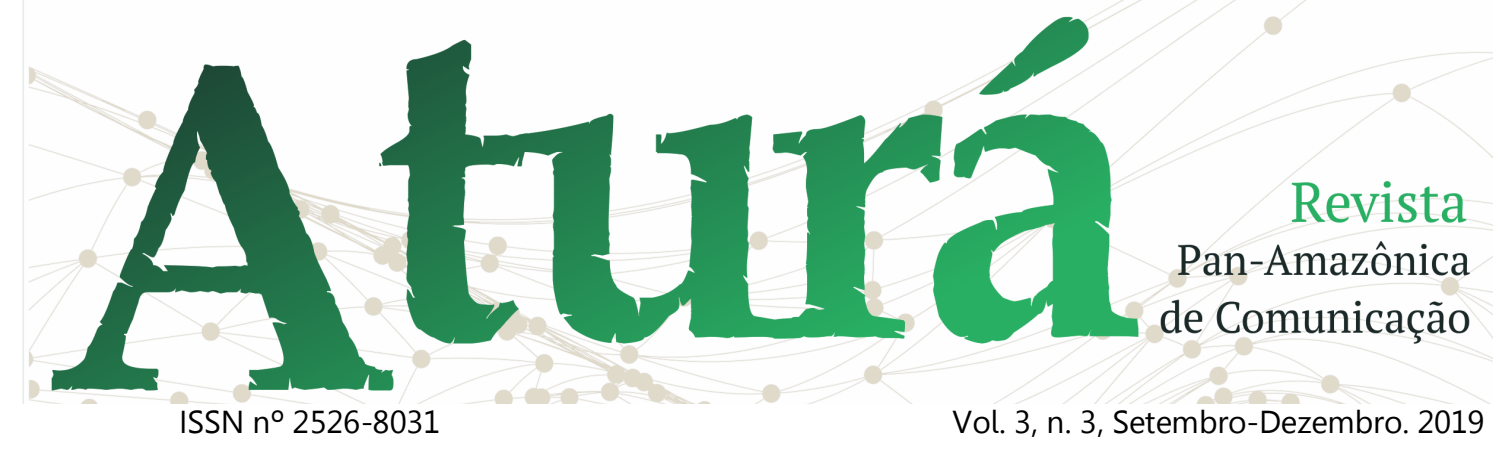

quem pertencia à elite, ou às camadas médias, e quem compunha a classe trabalhadora (DERENJI, 1998).

A partir de 1912, com a derrocada dos preços internacionais da borracha, a decadência da experiência modernizante da forma urbana de Belém fracassaria seguindo o próprio ritmo abrupto de falência das finanças públicas e das casas aviadoras da cidade. Sem o afluxo de capital proveniente da borracha, e sem a capacidade de manter o ritmo das obras públicas ligadas às reformas urbanas, além da intensa crise imobiliária vivenciada a partir de 1913, afetando o rendimento obtido por meio de aluguéis (CANCELA, 2006), uma parcela significativa da elite local retornou para suas regiões de origem ou migrou para outras capitais brasileiras (WEINSTEIN, 1993).

Nas décadas seguintes à crise da economia gomífera, entre as décadas de 1920 e 1950, a reestruturação da economia amazônica pela extração e exportação da castanha-do-Pará e fortalecimento do mercado interno regional permitiu a retomada do desenvolvimento reacomodando estruturas produtivas do extrativismo (COSTA, 2012), mas em patamares inferiores a 1870 o que significou a preservação quase total do patrimônio arquitetônico da Bélle Époque. Apesar do menor impacto no espaço urbano de Belém, em comparação com as décadas anteriores, as novas atividades industriais consolidaram novos grupos da elite, especialmente os proprietários de usinas de beneficiamento de castanha e de industriais de bens manufaturados.

No ciclo econômico da Castanha, de 1920 a 1960, a tipologia palacete perdeu o status simbólico de morada da elite, sem, entretanto, desaparecer da paisagem urbana de Belém. Isso se deve ao início da verticalização na área central, reforçando uma ideia de modernidade e progresso econômico associado à incorporação de edifícios residenciais multifamiliares (CHAVES, 2011) e somado às novas construções modernistas de residências de alto padrão encomendadas pela elite da castanha e da indústria.

Um novo padrão arquitetônico será instaurado em Belém, influenciando novos padrões tipológicos, com um ritmo moderado na renovação do ambiente construído na capital paraense, mas com a manutenção relativamente intacta do patrimônio edificado durante o século XIX, até o início dos anos de 1960. De fato, mesmo o processo de verticalização e adensamento da poligonal que atualmente corresponde ao Centro Histórico de Belém ${ }^{8}(\mathrm{CHB})$, manteve-se, nesse período, restrito aos eixos das

\footnotetext{
${ }^{8}$ Tombado a nível municipal desde 1994 e a nível federal desde 2012, o CHB inclui frações dos bairros da Cidade Velha e Campina, e possui área de entorno protegida que inclui parcelas dos bairros do Reduto, Batista Campos e Nazaré. Seus principais edifícios se encontram nos bairros da Cidade Velha e Campina, os quais representam os dois primeiros núcleos urbanos de Belém formados com a fundação da cidade no século XVII.
} 


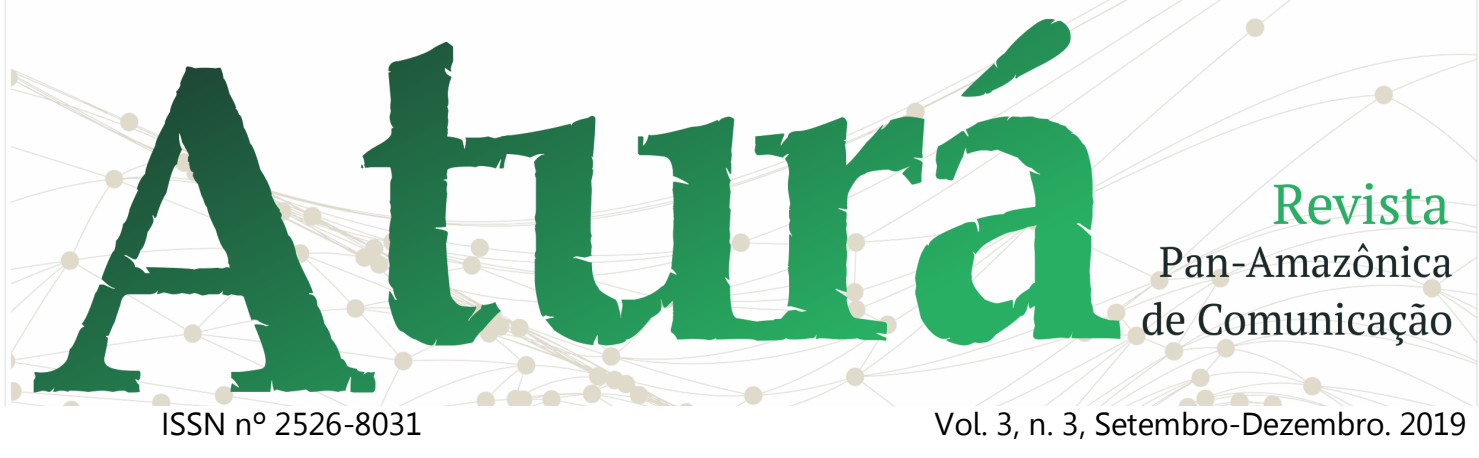

principais avenidas da cidade. Registros visuais, datados dos anos de 1950, demonstram o elevado grau de integridade do $\mathrm{CHB}$, com a clara identificação do casario eclético, dos grandes edifícios comerciais e industriais, bem como dos principais palacetes construídos durante as primeiras décadas do século $X X$.

Já nos anos de 1980, a memória de uma cidade de prédios luxuosos que ostentavam riqueza e prestígio influenciou diretamente as primeiras articulações em torno da preservação do patrimônio arquitetônico de Belém, notadamente os palacetes e casarios ecléticos construídos no auge do ciclo gomífero. Trata-se, na verdade, de uma relação que, segundo Riegl (1982), se liga a uma sensibilidade artística sobre o conhecimento histórico, em que as obras arquitetônicas antigas assumem um valor histórico-artístico na memória social urbana, compreendendo o histórico como a passagem de tempo e o artístico como a subjetividade que esses objetos passam aos apreciadores e desejosos de arte.

A crise econômica das décadas de 1980 e 1990 acentuou a degradação no centro histórico. A falta de investimento público em obras e serviços urbanos afastou o comércio de segmentos mais prósperos. Além dos surgimentos das legislações de tombamento do centro histórico e de proteção da sua área de entorno desacompanhadas por políticas públicas que não auxiliavam a permanência nele. Os custos de manutenção das edificações de moradia e de adaptação para novos usos, somados à dificuldade de linhas de financiamento, estimularam o abandono e a descaracterização dos edifícios, inclusive de grande parte dos palacetes que passam a dar lugar a novos edifícios multifamiliares ou são acolhidos pelo Estado para dar espaço a instituições públicas das mais variadas.

A partir da década 1990, observouse uma série de intervenções no $\mathrm{CHB}$ as quais discursavam por uma "devolução" do centro histórico sobre a ótica do 'resgate' da cultura. Desta forma, atreladas a políticas culturais, foram inseridas novas funções na área histórica como museus, galerias de artes e espaços de lazer em antigos prédios administrativos, religiosos, portos e etc. (LIMA e GUIMARÃES, 2009). Esse processo é característica do fenômeno mundial de revalorização de centros urbanos, que ocorreu também em outros países desde a década de 1960.

No caso de Belém, em particular, a invenção do CHB foi fortemente influenciada pela memória social coletiva estabelecida pelas heranças (ilusórias) de fausto e requinte da "Era da Borracha", condição expressa na política de preservação desenhada para o CHB e nas interpretações teóricas da elite artística e intelectual que se articulam para pautar o tombamento municipal dos bairros da CHB (GODINHO, 2019). Em função disso, a invenção do $\mathrm{CHB}$ expressa nas suas entrelinhas o pathos de 


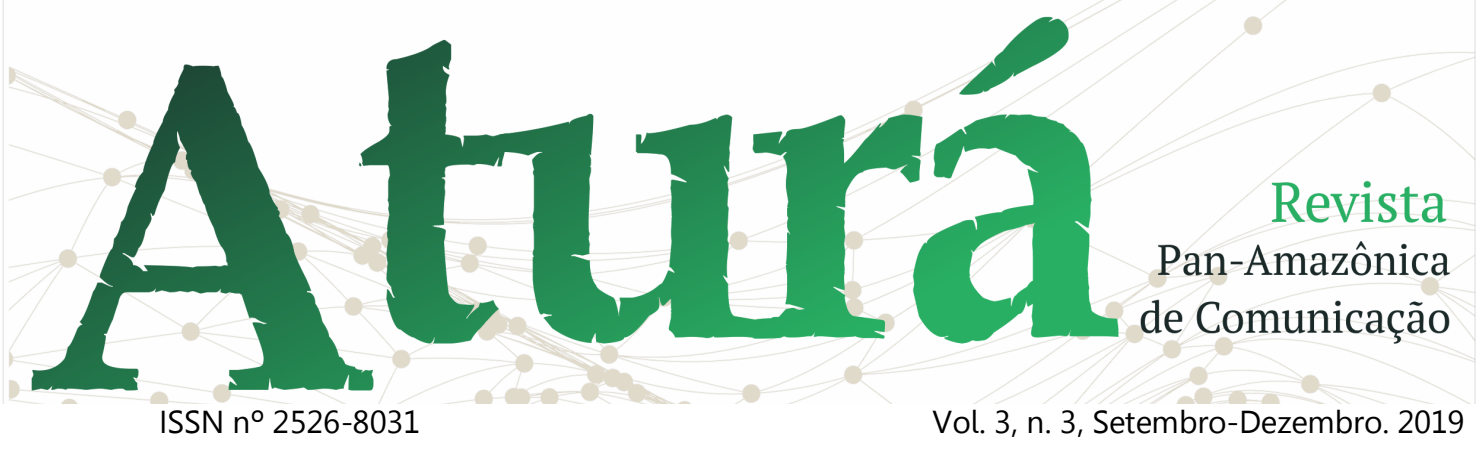

uma ausência celebrada por parcelas da sociedade local durante o século $X X$, e que se reconstrói nas narrativas que compõem uma memória social sobre o fausto atribuído ao ciclo da borracha, dotada de uma função terapêutica (CASTRO, 2010).

Desde o final dos anos de 1990, os palacetes Bibi Costa e Bolonha passaram à condição de patrimônio arquitetônico tombado da cidade de Belém. Tornam-se não só reconhecidos por lei como elemento da memória social da cidade, como asseguram a posteridade o seu caráter de inimitável e de distanciamento da realidade morfológica de grande parte das moradias que servem às camadas populares da metrópole. Como elementos componentes da memória social da "Era da Borracha" os palacetes Bibi e Bolonha estão na ponte entre o privado e o público e entre o familiar e o coletivo, simbolizando especialmente a dicotomia fausto-queda, uma relação assimétrica na qual "o lado da queda, traumático e chocante, prevalece" (CASTRO, 2010 p. 234) e, acima de tudo, aterroriza.

Por um tempo, Belém converteu-se em uma cidade com algumas centenas de imóveis vazios. Em uma cidade em crise, palacetes suntuosos, distantes da realidade da maior parte da população, intocados e fechados para visitações, permitiram que as narrativas sobre seus espaços internos ganhassem novos sentidos na construção da memória social de Belém. Essas narrativas alimentavam o imaginário da população e faziam recordar a suntuosidade da Belle Époque, bem como pontuava o sombrio do esquecimento, trazendo novos atores sociais para os palacetes: as visagens. Tudo isso produto de uma memória individual que passa a ser coletiva.

\section{As narrativas de assombração/visagem ${ }^{9}$ : interação e temporalidade}

O horror é um gênero que prevê a empatia e a interação como forma de comunicação, o que provoca medo é a possibilidade de estar no lugar do outro, de viver seus horrores, que o ouvinte/espectador apenas tem a possibilidade de experienciar (em partes) no plano da narrativa. $O$ horror também diz respeito ao que temos em comum com o outro, a consciência da possibilidade de morte, de dano, de sofrimento. Conforme afirma Lopes (2009, p.172), "desde o nascer que os humanos ficam expostos ao que pode darlhes a morte; o primeiro grito, motivado pela penetração do ar que se respira, é resposta a uma mudança violenta ao iniciar da relação com o exterior".

Essa comunicação, pautada na experiência comum da relação com o outro e com o mundo nos remete à noção interati-

\footnotetext{
${ }^{9}$ Considerando que o termo visagem é comum no território paraense, utilizaremos neste artigo, assombração e visagem como sinônimos. Portanto, ora utilizamos um ou o outro.
} 


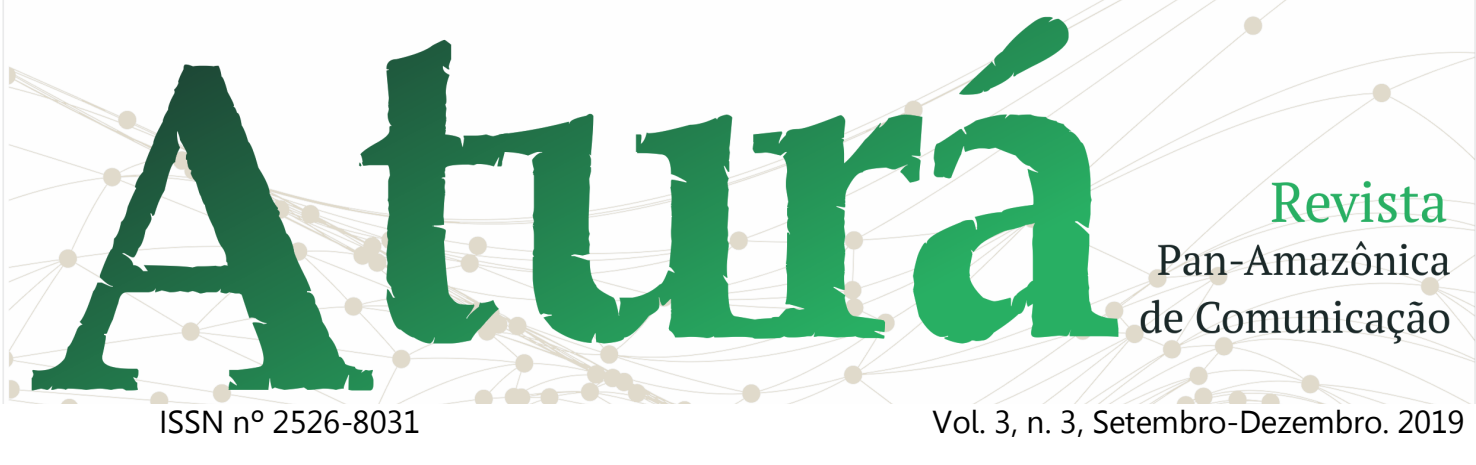

va da comunicação heideggeriana, que "deriva da evidência de que o dasein constitui, inexoravelmente, também, um mitsein" (CASTRO, 2013, 25), ou seja, o dasein constitui-se de um ser que se produz na coletividade (mitsein) e é dotado de intersubjetividade, também construída coletivamente. Castro (2013, p.26) apresenta a discussão de como o ser se comunica no mundo cotidiano, afirmando que nesse mundo em que ele é-com-outros, sua existência é pautada pelo coletivo e não tem sentido na solidão. Essa dimensão comunicativa do falar cotidiano é chamada por Heidegger (2005) de gerede, traduzida para o português como falatório, conceito que evoca a ideia de senso comum, de saber intuitivo, que está disponível a todos, que é ao mesmo tempo um saber e um nãosaber. Por isso, Castro (2013) evidencia que a superficialidade desse conhecimento pode aproximar as pessoas e intensificar as relações sociais. Na medida em que é comum a todos, torna-se ponto de encontro, de trocas e de afetos.

O falatório de Heidegger (2005) está orientado para o tempo futuro, como possibilidade. Ele próprio se confunde com o tempo, são análogos para o dasein, é o que "configura o presente no futuro e acomoda o passado" (CASTRO, 2013, p.29). Desta ótica de análise, o conceito de falatório, assemelha-se ao de configuração narrativa em Ricoeur (1994), como tarefa contínua de configuração do mundo da vida, análo- go ao mundo cotidiano de Heidegger (2005), abordado a partir da tessitura da intriga.

A intriga/narrativa só é possível dentro de uma construção temporal, "o tempo tornase tempo humano na medida em que é articulado de um modo narrativo, e a narrativa atinge o seu pleno significado quando se torna uma condição da existência temporal" (RICOEUR, 1994, p. 85). Ao emprestar o conceito de intriga de Aristóteles, o autor percebe uma imitação da ação, colocada dentro da narrativa, que configura e organiza de modo a fazer sentido. Ao flexionar tempo e intriga encontramos o tempo do mundo cotidiano, o tempo humano, possível apenas pela capacidade de narrar e unir fragmentos heterogêneos em uma ordem e lugar que adquirem coerência e lógica dentro do paradigma narrativo.

Ainda na perspectiva da indissolubilidade temporal, a intriga ricoeuriana se insere na temporalidade do triplo presente, também chamado presenteísmo. Nele, o ser está sempre repartido nas três temporalidades, suas ações presentes utilizam como base as memórias do presentepassado para ter atenção e agir no presente-presente, porém com uma intenção e expectativa de resposta voltada para o presente-futuro. O ponto de aproximação entre falatório e tessitura da intriga/narrativa encontra-se na temporalidade futura. Em ambos os casos a narrativa gera uma expectativa orientada para o futuro. 


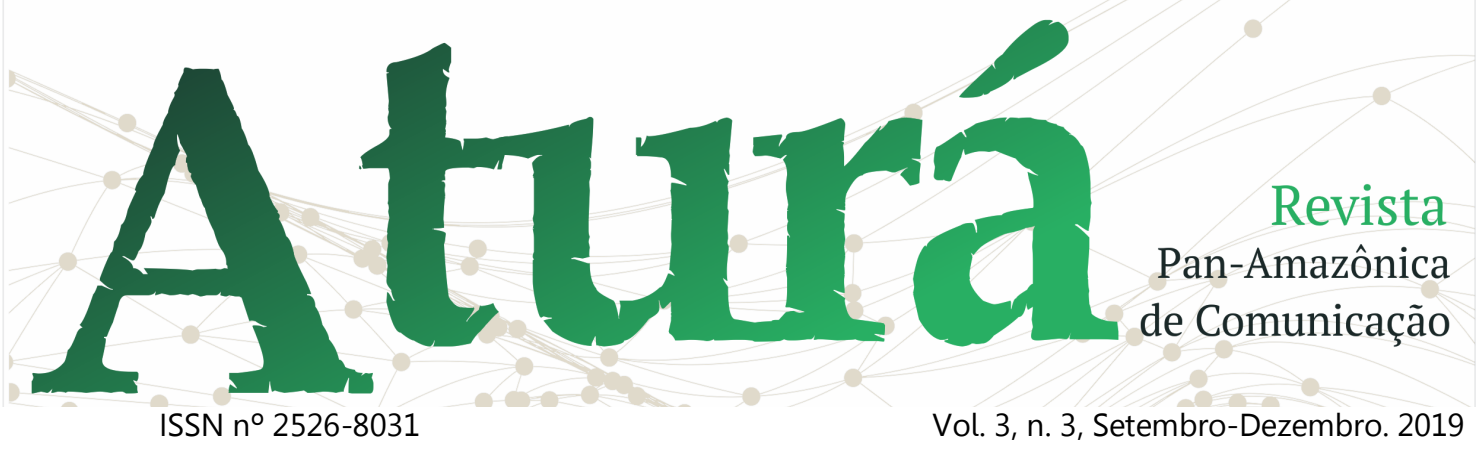

Analisamos esse tempo pela lógica da narrativa, pois o tempo do narrado não corresponde ao tempo cosmológico, como identificamos nas análises das narrativas de assombração. Os tempos presente, passado e futuro podem se deslocar, comprimir, inverter, dilatar, convertendo-se de fato em uma oposição ao tempo, visto que "o tempo da ficção liga entre si momentos que o tempo real separa" (NUNES, 2013, p.25).

Aproximando as narrativas de assombração das narrativas literárias de ficção, podemos intuir que estão no plano imaginário, de modo que o tempo surge com a apresentação de cada ação e a relação que as costura. Neste ato de vincular cada ação, que pode ser entendido como a configuração do enredo narrativo, na perspectiva ricoeuriana, alguns eventos são evidenciados, outros invizibilizados, a temporalidade dos eventos não é clara e tampouco importante para a compreensão da intriga, esta, apresenta características do falatório, pois não carece de comprovação de veracidade e nem de maiores esclarecimentos para gerar afetação ou curiosidade, além de manter preservado o caráter ambíguo da narrativa. Principalmente na narrativa de horror, que precisa suscitar a dúvida, o componente da ambiguidade reforça o mistério, suspense e deixa a possibilidade em aberto (MARTINS e NICOLINI, 2017). A história fica aberta tanto para o real, quanto para o ficcional.
O que possibilita a aproximação entre a configuração da intriga em Ricoeur (1994) e o falatório em Heidegger (2005), é a possibilidade de estar junto, de ser-com-outro na vida comum, sem necessariamente precisar comunicar ou fazer sentido. Diante disto, decidimos pensar nas histórias de visagem como uma narrativa configurada pela lógica do falatório, visto que se orientam menos para a veracidade e para o sentido da história em si, do que para a interação e os sentidos produzidos no mundo cotidiano, na criação de memórias entre as pessoas. Elas sobrevivem ao tempo, às mudanças nas dinâmicas urbanas e tecnológicas, e mesmo sem possuírem fontes históricas e comprovações, são compreensíveis a todos.

O falatório se realiza a partir da ambiguidade e da curiosidade (CASTRO, 2013), e ambas as características nos interessam nas narrativas de visagem, primeiramente a ambiguidade, pois ela garante que o dasein nunca esteja certo, nunca pode comprovar a veracidade do seu encontro com o que se encontra no cotidiano. Depois a curiosidade, é ela que funciona como impulsionadora do falatório, ela o projeta para adiante e, assim, permite sua propagação.

Uma questão importante para nossa análise, levantada por Castro (2013), é a tecnologização da experiência comunicativa, ela proporciona novas forças ao falatório, atribuindo nova dinâmica. Refletimos 


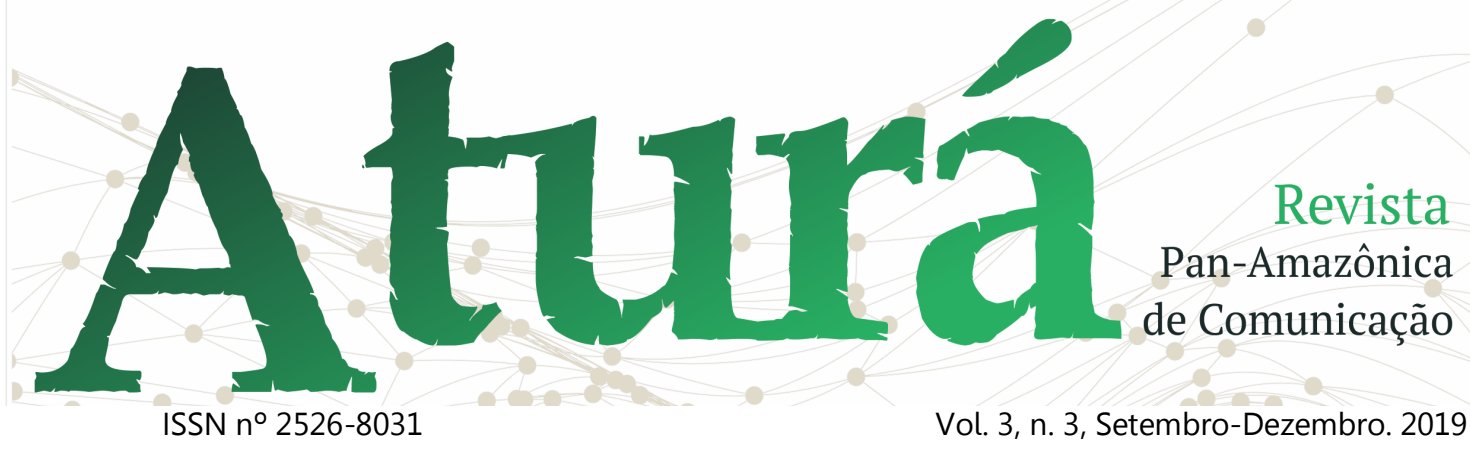

sobre essa dinâmica no âmbito do objeto deste artigo, as histórias de visagens e de casas mal-assombradas, que antes eram contadas nas portas das casas, passaram a integrar sites, perfis em redes sociais, blogs e canais na plataforma de vídeos Youtube. Esses novos ambientes de propagação modificam a dinâmica de interação por meio dessas histórias, fazem parte da composição de uma memória comum e de um imaginário social da cidade de Belém, descrita pelo autor do livro "Visagens e Assombrações de Belém", Walcyr Monteiro, como uma cidade que sempre foi visagen$\operatorname{ta}^{10}$.

Monteiro (2016) afirma que quando iniciou a escrita do seu livro buscava preservar esse traço cultural, que acreditava estar fadado a desaparecer, pois era transmitido oralmente, quando famílias e vizinhos se reuniam nas frentes das casas para compartilhar histórias assustadoras sobre visagens. Essa tradição faz parte da memória social de Belém, pois, apesar da urbanização, não escapou à fascinação do sobrenatural. A tradição oral das lendas foi sendo propagada a partir do impacto cultural de cidades do interior na capital Paraense, que transmitiam, a partir da narrativa, o

${ }^{10}$ O Liberal. O sobrenatural pede carona: conheça histórias assombrosas de Belém. 2019. Disponível em: < https://www.oliberal.com/o-sobrenaturalpede-carona-conhe\%C3\%A7a-hist\%C3\%B3riasassombrosas-de-bel\%C3\%A9m-1.123026>. Acesso em: 13 jun. 2019. medo de certos lugares (TOCANTINS apud MOTEIRO, 1963).

Nos dois vídeos selecionados para análise, com a denominação de "Belém Assombrada - Bibi Costa" e "Belém Assombrada - As assombrações do palacete Bolonha", buscamos compreender o papel das histórias de visagens na construção de memórias e na configuração do imaginário social de Belém, analisando a ressignificação do espaço histórico da cidade e refletindo sobre a comunicação banal, cotidiana e como ela se configura enquanto narrativa com marcas da oralidade, adaptadas ao ambiente tecnologizado.

\section{A configuração das narrativas da Belém Assombrada na cotidianidade}

Para empreender nossa análise, nos inspiramos em alguns movimentos da análise narrativa, desenvolvidos por Motta (2013), com base da fenomenologiahermenêutica ricoeuriana. Recorremos mais especificamente à compreensão da intriga, e ao movimento que tem como foco as estratégias argumentativas. Buscamos marcas dos fenômenos característicos da experiência comunicativa e interativa do dasein no cotidiano. Com esta análise, compreendemos como, na comunicação marcada pelo falatório, pela curiosidade e pela ambiguidade, o ser configura suas memórias, suas certezas e suas próprias narrativas da cidade e do espaço social. 


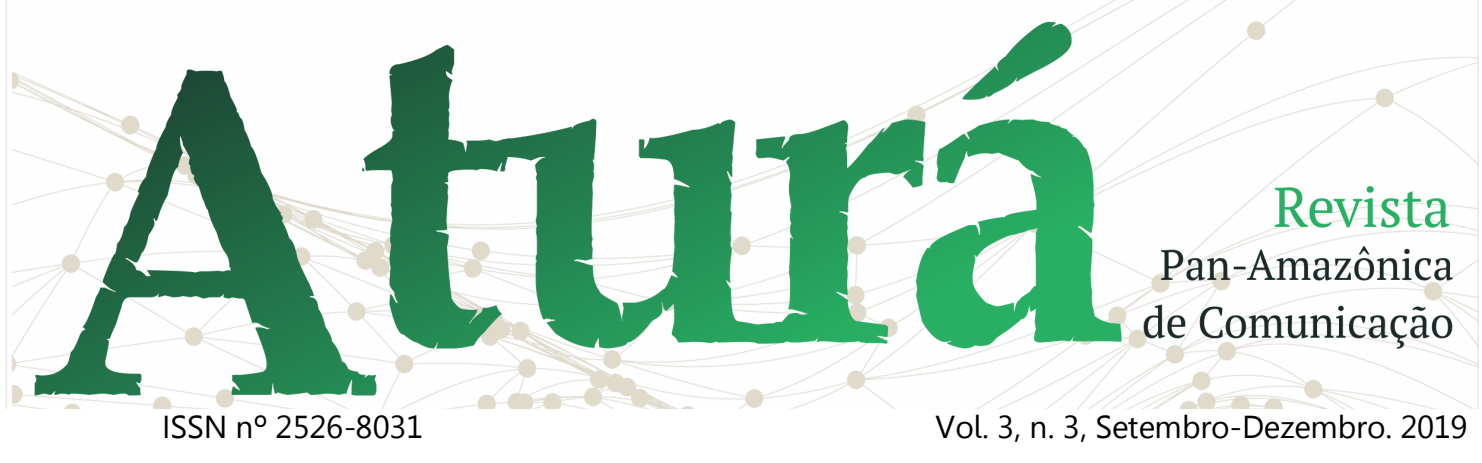

Analisamos como encaixam-se as ações, como os eventos conectam-se nas diferentes temporalidades, fazemos também uma observação dos recursos da linguagem utilizados, bem como procuramos, na dimensão da linguagem, identificar as estratégias argumentativas que intentam provocar efeitos do real e efeitos estéticos de sentido.

\section{a) Vídeo 1: "Belém Assombrada Bibi Costa".}

Nossa primeira análise está centrada no vídeo sobre o Palacete Bibi Costa, que possui $3 \mathrm{~m} 24 \mathrm{~s}$ de duração, 4.619 visualizações, 141 likes, quatro dislikes e 19 comentários ${ }^{11}$, foi publicado em 26 de agosto de 2015. Segundo a descrição do vídeo o palacete, que tem uma história de torturas e assassinato de escravos, é considerado um dos lugares mais assombrados do Brasil.

A narrativa começa com pretensões históricas, com fotos do prédio e textos sobrepostos às fotos. Major Brício Costa, conhecido como Bibi Costa, encomendou a construção do palacete a Francisco Bolonha para hospedar o então presidente da República, Afonso Pena, e sua comitiva. Para ilustrar, fotos do Major, do presidente e sua comitiva são mostradas. Apesar do breve contexto histórico, estão ausentes as fontes de pesquisa e informações mais detalhadas sobre o palacete. Bibi Costa era o

${ }^{11}$ Até o dia 07 de agosto de 2019. palacete de campo que a família do Major usava para se manter longe das camadas mais populares (ARRUDA e SANJAD, 2017).

A cidade foi urbanizando-se e, hoje, o palacete Bibi Costa está inserido em uma das áreas centrais de Belém, o bairro de Nazaré. Os moradores da metrópole conhecem o lugar, pois o abandono do palacete destoa dos prédios luxuosos do entorno. Desta maneira, o vídeo pretende provocar a memória individual do espectador a partir da narrativa e das histórias que pertencem a memória coletiva da cidade, tendo em vista as lendas sobre o lugar. Dando conta dessas memórias, o vídeo opta por um percurso de apresentação ocultando o sujeito da narrativa "Conta a história que, em 1904, o Major Brício Costa (...)" (SENHORA MORTE, 2015), sendo assim, o sujeito é a própria história, que segue contando a si mesma.

O local foi vendido ao seringalista Júlio Andrade, em 1910, após a morte do Major. Neste trecho do vídeo, várias imagens que ilustram o ocorrido são colocadas em sequência, como um coração acorrentado, instrumentos de tortura e pessoas negras acorrentadas ou em sofrimento, tendo em vista que a memória popular acusa Júlio de aprisionar e torturar negros após a abolição da escravatura, "a maioria doente, com sede e famintos, não suportavam os maus tratos e morriam em condições sub-humanas" (SENHORA MORTE, 2015). 


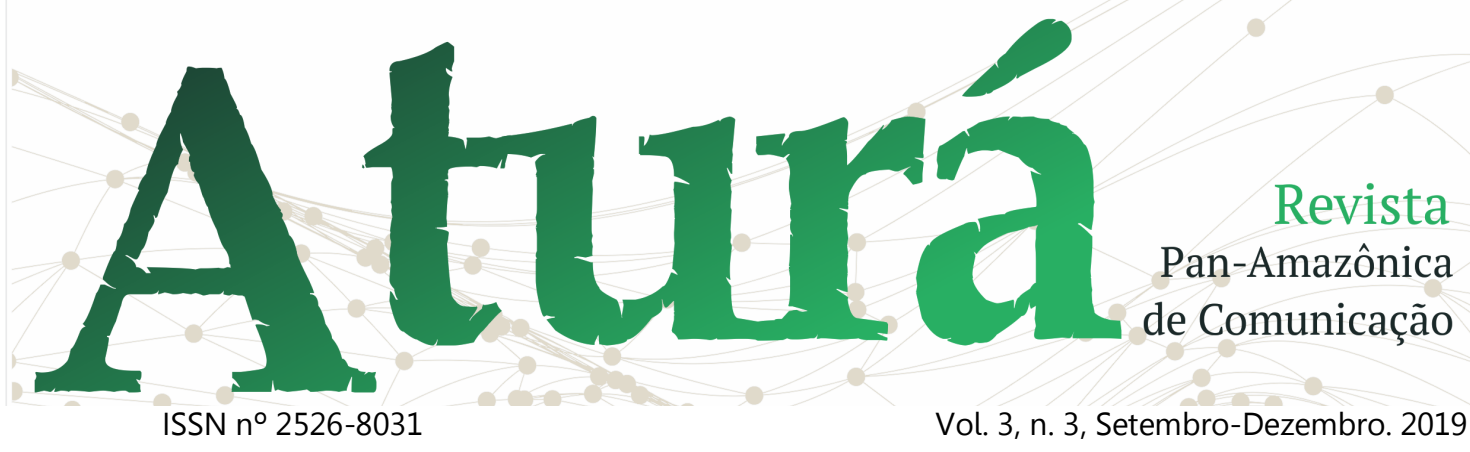

Além de transportar para um tempoespaço passado, a partir de uma temporalidade própria, a narrativa orienta para implicar o real, para a não interferência do narrador e para a abrangência e certeza generalizante, típicas do falatório. Visto que o falatório "evoca uma vacuidade no dizer, o excesso de sentido que leva à ausência de sentido" (CASTRO, 2013), pois é a possibilidade de compreender tudo, sem se apropriar previamente da coisa, bem como dispensa a tarefa de uma compreensão autêntica do dasein, isto é, da reflexão ontológica que causa angústia, além de elaborar uma compreensibilidade indiferente, da qual nada é excluído (HEIDEGGER, 2005).

O narrador abre o sentido e ao mesmo tempo o esvazia. O vídeo alude a fatos históricos, porém para compreendelo não é necessário um conhecimento prévio, tampouco o narrador fornece explicações detalhadas, confirmando a característica do falatório de não aprofundamento das informações. Sendo assim, da mesma forma que proporciona uma abertura do dasein para o mundo, também representa um fechamento ontológico, um não retorno ao referente na busca de sentido, assim como a ausência de necessidade de comprovação. Os fatos, relatos, experiências, vivências e as histórias estão no mundo, entre os entes e é o que proporciona o conhecimento de muitas coisas de forma média, banal e comum.

No conteúdo sobrenatural, para despertar a curiosidade, o narrador diz "foi então que fatos estranhos começaram a ocorrer no local" (SENHORA MORTE, 2015), dando um salto temporal do passado confrontando com uma espécie de presente sobrenatural. Há efeitos estéticos de sentidos presentes na expressão "fatos estranhos", o que seriam esses fatos? O que podemos entender por estranhos? Entramos na curiosidade e na subjetividade da interpretação, que desperta um estado de inquietação frente a história que desenrolará. Heidegger (2005), ao discorrer sobre a curiosidade, evidencia que ela prima pelo novo, pelo ainda não visto, provocando no dasein excitação e interesse pela novidade, não para compreender o objeto da curiosidade de fato, mas para vê-lo, enquanto coisa ainda não conhecida.

O vídeo relata o caso de Sr. Augusto, um ex-funcionário da Secretaria (que passou a funcionar no palacete). A narrativa passa em dezembro de 1980, por volta de 17h30. Quando todos tinham ido embora, Sr. Augusto ouviu uma voz chamar, dirigiuse ao porão, tentou acender as luzes sem sucesso e a voz disse:

Não acenda a luz, venha aqui, preciso da sua ajuda...'. Ao olhar pra baixo, viu um homem negro, acorrentado à parede, estava machucado e implorava '- Me tire daqui, não aguento tanto sofrimento!'. Apesar do pavor que 


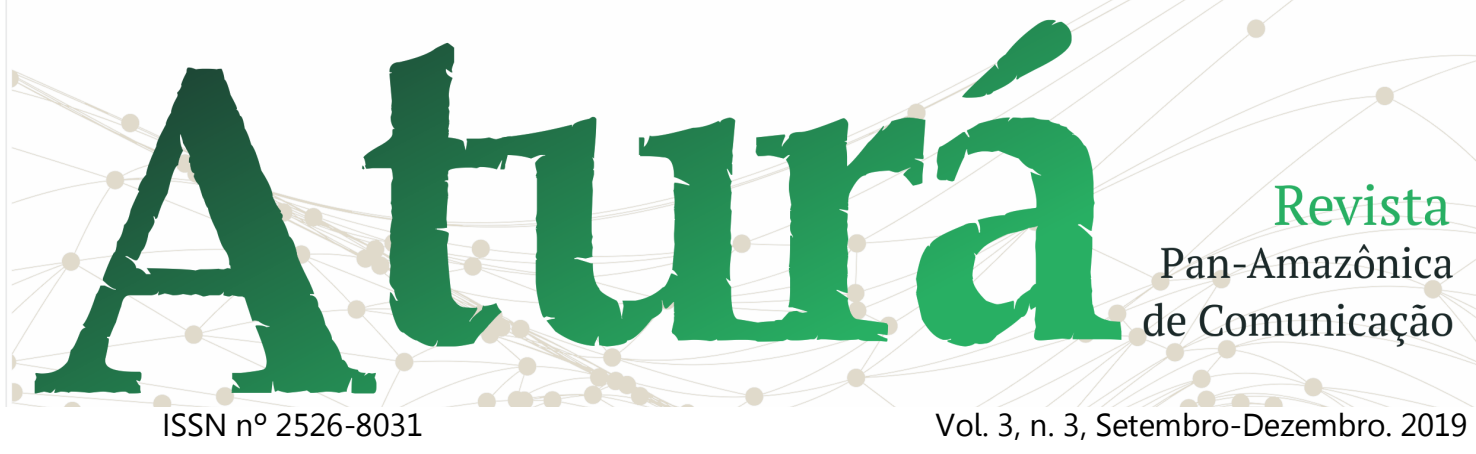

sentiu, ele arrumou forças e correu dali. (Senhora Morte, 2015).

Este trecho traz um caso específico no drama principal, o que Motta (2013) nos apresenta como uma espécie de trama dentro da trama. A alusão a um nome próprio, de um funcionário, que é colocado como alguém que vivenciou a história sobrenatural, produz efeitos do real (MOTTA, 2013), assim como a apresentação precisa das marcas temporais na história, "era dezembro", "por volta das 17:30", visam amenizar possíveis dúvidas em relação à veracidade dos acontecimentos.

Sr. Augusto, apesar de protagonizar a narrativa, não se constitui de uma fonte segura, nem temos certeza se existe ou mesmo se ele se chama Augusto, tendo em vista que o narrador deixa o sentido em aberto pela expressão "aqui chamado Sr. Augusto". Essa possibilidade permanentemente em aberto, em Heidegger (2005, p. 234) está associada à ambiguidade, o autor inclusive utiliza a expressão "seguir pistas". O que nos leva a crer que o que impulsiona a ambiguidade é justamente a curiosidade e o falatório. Este último pressente e intui sobre aquilo que diz, sem a necessidade de que seja verdade ou que se concretize, assim, impulsiona a ambiguidade mais ainda quando não se concretiza. No plano semântico, o uso de hipérbole "a mais assustadora" para introduzir o caso, constitui-se de um efeito estético de sentido que busca suscitar a curiosidade, no plano da temporalidade futura, sugerindo o novo, que enquanto é novo e não sabido produz efeitos de sentidos mais intensos, como os descritos por Heidegger (2005) como estado de excitação, de impermanência, que prioriza o novo em detrimento do que está próximo, do que se torna presente.

A expressão no vídeo "Belém Assombrada Bibi Costa" que nos transporta ao presente da narrativa é justamente "hoje, o palacete Bibi Costa encontra-se fechado, para o desespero dos fantasmas, que precisam de alguém com coragem para quebrar suas correntes e libertá-los" (SENHORA MORTE, 2015). O vídeo finaliza com um desenho em preto e branco do palacete, atrás de um desenho de correntes sobrepostas, remetendo ao passado de sofrimento e ao sentido do palacete como prisão, primeiro de pessoas e depois de visagens.

\section{b) Vídeo 2: "Belém Assombrada - As Assombrações do Palacete Bolonha".}

Vídeo com 9m39s de duração, 18.028 visualizações, 816 likes, 12 dislikes, 76 comentários ${ }^{12}$, publicado em 25 de abril de 2016. Na sua descrição apresenta o Bolonha como um dos lugares mais assombrados de Belém do Pará. De acordo com o vídeo, o palacete foi construído, como um

\footnotetext{
${ }^{12}$ Até o dia 9 de agosto de 2019.
} 


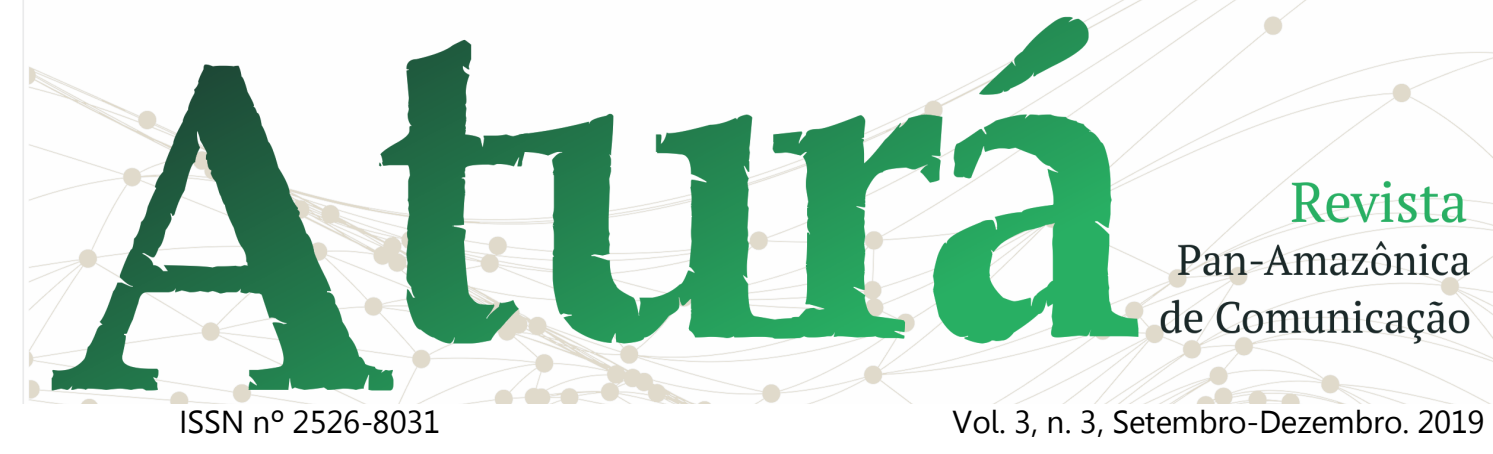

presente do arquiteto Francisco Bolonha para a esposa, como prova de amor. Não há confirmação de que o palacete seria um presente romântico, mas a história de amor, se não é real, é ben trovata (Coimbra, 2014), tendo em vista que faz parte da memória social dos moradores de Belém, que um palacete no estilo eclético, com caraterísticas do gótico e art noveau (COIMBRA, 2014) teve uma motivação amorosa. A história da família Bolonha entrelaça-se à memória da cidade, promovendo curiosidade, falatório e estimulando a imaginação social como "uma porta aberta para o mundo do sobrenatural" (SENHORA MORTE, 2016).

O tema sobre o palacete começa após uma vinheta, com foto do edifício envolta em névoa, que aparece junto à narração: "E aí galera assustada? Senhora Morte vai abrir as portas de um dos lugares mais assombrados de Belém do Pará" (SENHORA MORTE, 2016). A sentença funciona na verdade como um convite a quem assiste e busca despertar a curiosidade. De acordo com, Heidegger (2005, p.233), a curiosidade incita o dasein a ir pulando de uma novidade a outra, ela caracteriza-se por uma constante impermanência junto ao que está próximo, assim como a prioridade ao que está distante, característica também presente na comunicação tecnologizada, que prima pela novidade, pela agilidade na comunicação, além da aproximação do que está distante, por meio da facilidade de acesso a conteúdos.

O vídeo apresenta imagens da fachada e alguns cômodos do Palacete. No avançar da narrativa sobrenatural aparecem algumas imagens sem relação com o Bolonha, para efeito de ilustração. Em relação à história, narrada no vídeo, o Palacete Bolonha, construído, em 1905, durante o auge do ciclo da borracha, está cercado de relatos de "aparições espectrais, ruídos inexplicáveis e outras formas de atividades paranormais" (SENHORA MORTE, 2016). A ambiguidade está presente em diversas passagens da narrativa, apoiada em expressões generalizantes, como "são muitos os relatos", ou a referência à "lista dos lugares mais assombrados da cidade" (Idem, 2016). A lista, obviamente, não é um registro oficial, mas obedece aos critérios da própria narradora, não manifestados claramente no texto. A narrativa faz um jogo entre efeitos de realidade e estéticos de sentido ao contar a história do Palacete em alguns momentos, intercalando com histórias de assombrações.

Junto à narração dos detalhes arquitetônicos do palacete, fotos dos azulejos com as iniciais douradas de Francisco Bolonha e móveis da sala de jantar são mostradas. Outro ponto chave da composição do enredo está na história dos personagens. O dono e responsável pela construção, Francisco Bolonha, é mostrado como uma figura trágica, com uma história de 


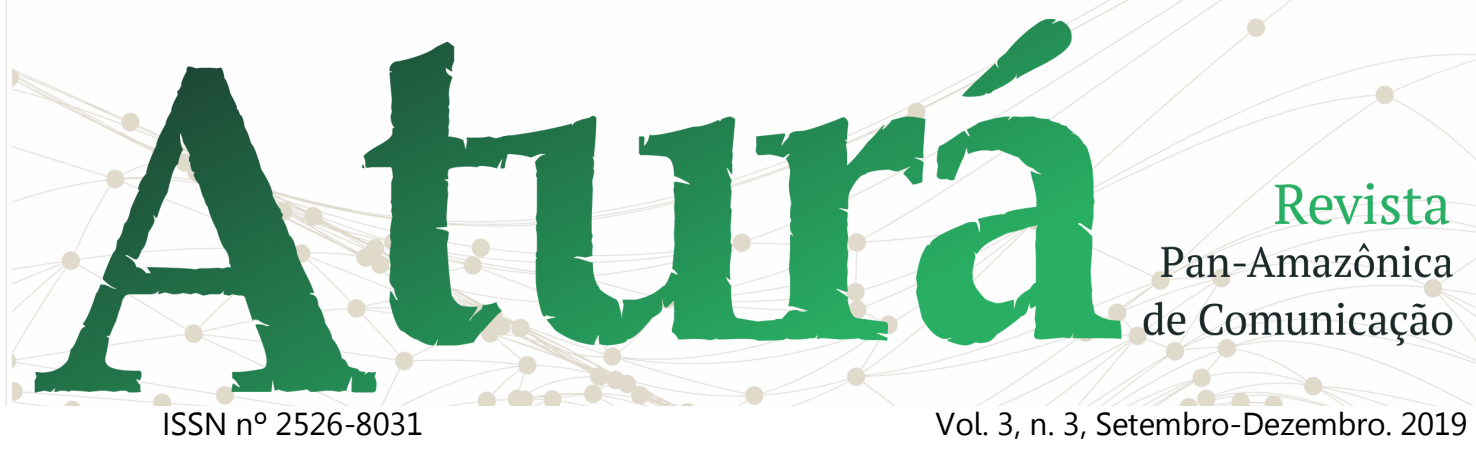

vida bem-sucedida financeiramente, porém infeliz nas relações.

A narrativa tem um ponto de virada após a morte de Bolonha e sugere em vários momentos que o próprio personagem se converteu em um dos fantasmas que assombram o palacete. A despeito da história do próprio Francisco, a narrativa se passa em dois tempos, no começo dos anos 1900, quando ele conhece sua esposa, Alice Tem-Brink, e o constrói como um presente para ela, e o segundo tempo, presente, quando o espaço já se encontra fechado, em um estado de abandono, o qual permite que narrativas populares floresçam. Além da história das tragédias acerca da vida do próprio Francisco Bolonha, a narradora configura a história de tragédia do local de construção do palacete, fatos que poderiam parecer aleatórios, não fosse tecida a síntese do heterogêneo, imprescindível para a configuração narrativa. Ela afirma que o terreno onde o palacete foi construído "tratava-se de um local com um solo alagadiço, cercado por um matagal peçonhento e perigoso, aonde muitas vezes foram desovados os cadáveres de vítimas de assassinatos" (SENHORA MORTE, 2016).

As afirmações que ligam as aparições sobrenaturais à morte e corpos marcados pela violência são cercadas de adjetivos que provocam efeitos de sentido, além de estarem inseridas no âmbito do falatório, visto que está na ordem da medi- anidade do discurso, não requer a compreensão integral, nem créditos referenciais ao ente que o produziu, o importante é "seguir adiante e ser propagado" por um número cada vez maior de entes. Por isso, Heidegger (2005) assume o caráter autoritário e ao mesmo tempo vazio de sentido e despojado de solidez do falatório. Essas características estão presentes no excerto "o palacete foi a flor que nasceu das profundezas lodosas e mascarou a tétrica reputação do local, conferindo beleza aos olhos locais e indignação às almas que por ali vagavam em busca de justiça" (SENHORA MORTE, 2016). Aberto à interpretação e à crença de quem escuta, ele também não indica seu referente, ao mesmo tempo em que é categórico, não pode ser confirmado.

A narrativa retorna ao seu personagem principal mais uma vez, em um jogo de quadros narrativos que vão do personagem para o cenário e do cenário para o personagem. Percebemos a construção de uma relação de sentido entre a decadência física e espiritual do cenário e degradação moral do próprio personagem. Essa configuração fica evidente no excerto que descreve as mudanças de comportamento de Francisco Bolonha, de bom marido e homem apaixonado a um homem propenso ao adultério e à devassidão.

Com o passar do tempo o comportamento de Francisco Bolonha mudou, dizem que ele se desgostou 


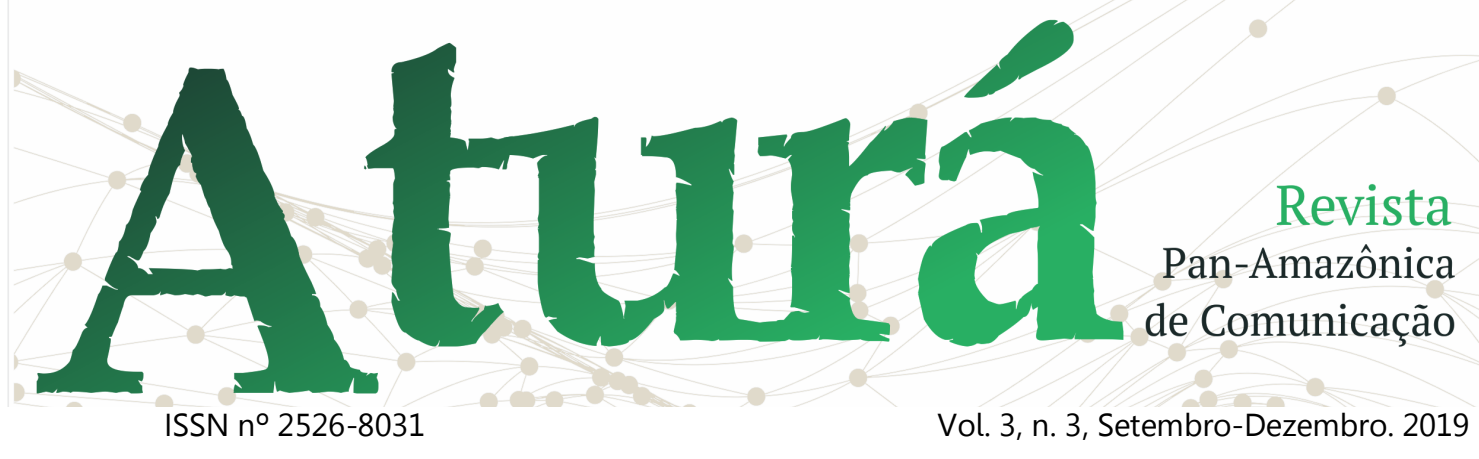

com o casamento porque Alice não pôde the dar filhos, pois ele adorava crianças (...) Contam que ele se tornou um homem licencioso, que costumava fazer orgias com prostitutas francesas e dar banho nelas na banheira de mármore (...). Enquanto isso acontecia, a esposa ficava fechada, chorando em seus aposentos. (SENHORA MORTE, 2016).

Neste ponto do vídeo, as imagens do próprio palacete dão lugar a imagens genéricas e mais ilustrativas, a descrição da energia espiritual do lugar é definitivamente vinculada a energia construída em torno do personagem. As características da imprecisão da comunicação cotidiana marcam o discurso com informações sem referentes e descontinuadas, que lança dúvidas sobre a veracidade do texto, ao mesmo tempo que buscam aguçar a curiosidade do ouvinte, mencionando o tempo presente como uma possibilidade, como uma narrativa que continua até hoje. A memória coletiva vai tomando forma a partir das lendas urbanas misturadas aos fatos históricos ligados ao lugar e aos personagens.

Algumas das características do falatório, a impossibilidade do retorno ao referente, assim como a ambiguidade são colocadas na temporalidade presente, em uma narrativa que permanece em aberto e que não se encerra com a morte dos protagonistas, ela se desdobra em novas nar- rativas na Belém do presente e continua afetando a vida de pessoas que não conheceram os personagens principais, a não ser pelas histórias imaginadas, tecidas pela imaginação popular, como a explorada pelo objeto de nossa pesquisa. Podemos perceber essas características no excerto "alguns pesquisadores paranormais acreditam que o casal ainda vive no palacete, presos a um passado de opulência e sofrimento" (SENHORA MORTE, 2016).

O vídeo vai chegando ao fim e percebemos a mudança de temporalidade, somos "transportados" pela narrativa para o tempo presente, que pode ser tanto o presente de quem está assistindo, quando o momento em que o vídeo foi feito. A narrativa cria um tempo próprio, que flui de acordo com o avanço dos acontecimentos, mas que também é estanque em relação ao momento em que foi escrito, ou seja, é, conforme indica Nunes (2013), tanto o tempo quanto o avesso do tempo.

\section{Considerações finais: Espaços abertos ao imaginário}

Notamos que o vídeo da análise referente ao Palacete Bibi Costa utiliza estratégias para provocar no ouvinte/espectador a impressão de que o falado constitui-se de fatos reais, como se eles falassem por si mesmos e não fossem influenciados pelo narrador, já o segundo, referente ao Palacete Bolonha, utiliza dis- 


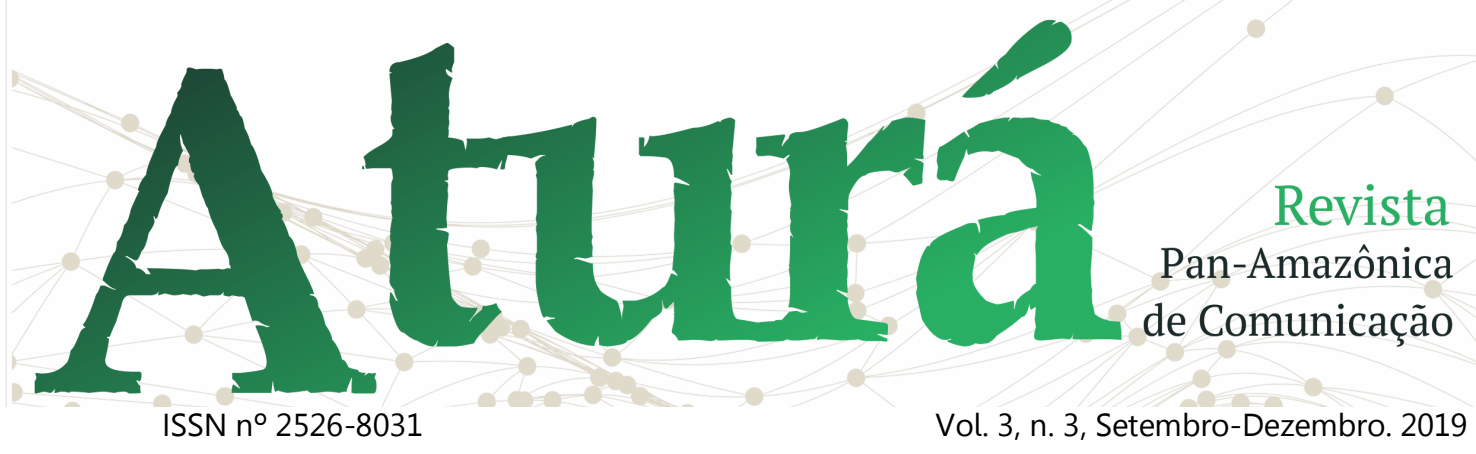

positivos que buscam provocar sensações no ouvinte/espectador, assim como impressões mais subjetivas, seguindo um projeto dramático, que utiliza de efeitos de sentido poéticos e simbólicos (MOTTA, 2013), frequente nas narrativas de ficção e nas artes. O vazio humano do espaço em desuso dá lugar a um espaço preenchido pelo imaginário, no qual os espaços físicos ganham significados na medida em que compõem um repertório de memória, em que se imbricam passado/presente ao relacionar suas histórias e seus significados dentro do espaço urbano.

Portanto, a memória é mais que uma representação do passado, ela é fragmento da temporalidade desse passado, implicando numa dialética entre passado, presente e futuro. Por isso, há uma possibilidade da relação com esse espaço-temporal ser marcada por sentimentos e magias. Essas sensações podem ser atravessadas positivamente ou negativamente, dependendo da afetação que o indivíduo sofre. Levando em consideração que a memória é a capacidade de atribuir lembranças a lugares, a imagens, a objetos, a sons ou odores, criase uma relação em que o espaço se metamorfoseia no tempo. Sendo assim, as lembranças podem gerar sentimentos como saudade, medo, amor, horror, entre outros, que criam sociabilidades entre espaço físico e imaginário.

A memória tem, assim, a dupla dimensão do público e do privado (RICOEUR,
1994), estando atrelada a noção da experiência interior e da percepção de que a memória pode ser influenciada pelo imaginário, isso porque ela é uma construção social e um fenômeno coletivo (HALBWACHS, 1990). A principal função da memória, como imagem partilhada do passado, é promover um laço entre os membros de um grupo com o seu passado coletivo, cristalizando valores e a ilusão de imutabilidade. Para Halbwachs (1990), a memória coletiva faz parte da identidade de um grupo, assegurando a sua continuidade no espaço-tempo.

Nesse sentido, convém destacar que tudo que recordamos como indivíduo é condicionado, pois pertencemos a um grupo. Por isso a memória individual está inserida e estruturada na memória coletiva, na qual há experiência vivida, afeto e história. Desta maneira, os lugares tornam-se vestígios de fragmentos de um tempo passado e imagens presentes nas lembranças. Essa memória não é intacta, tendo em vista a condição de vestígio dos detalhes vividos, mas possibilita a transformação dos fragmentos desse tempo em relatos que tornam as arquiteturas de certa maneira inteligíveis, como lugares do passado (SILVA, 2002).

As lembranças fortificam-se nas narrativas coletivas, que são transmitidas de grupos em grupos e muitas vezes de gerações em gerações, ajudando a construir uma memória coletiva reforçada por meio 


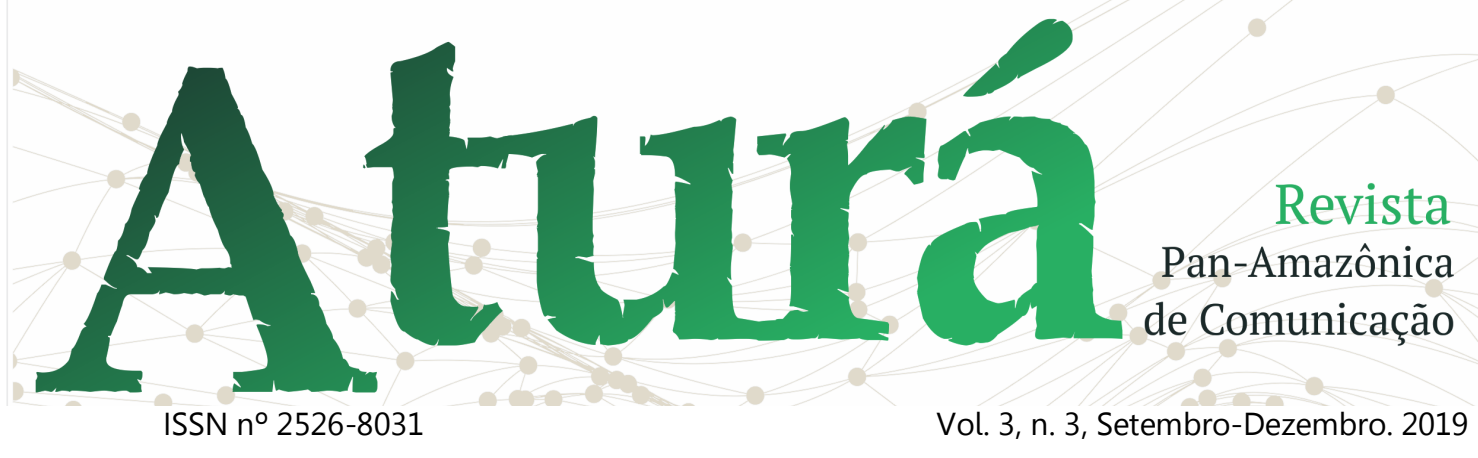

de celebrações públicas de acontecimentos que marcaram a história coletiva. $O$ caráter seletivo da lembrança permite que haja uma instrumentalização da memória em busca de um universalismo da rememoração de acontecimentos passados com significados do tempo presente, inclusive valores morais.

Assim, a memória é o único recurso de referência ao passado que temos, mesmo sendo uma construção do presente. Dessa maneira, a temporalidade, vista como a relação do homem com o espaçotempo, é negociada e, de certa maneira, manipulada, já que as imagens das lembranças individuais/de grupos sociais são transformadas em coletivas por meio de elementos estruturadores da memória: ver, cheirar e ouvir. Essa memória sensível conecta a memória individual e a social.

A memória da Era da Borracha não se desfez com o declínio daquela atividade produtiva. A população urbana de Belém continuou, por muitas décadas, vivenciando a experiência do fausto ilusório materializado no modo de vida e no ambiente construído da cidade: praças com coretos de ferro importados, teatros de inspiração europeias, colégios de alto padrão construtivo, mercados e porto em estruturas prémoldadas de ferro fundido, e especialmente, os antigos palacetes das famílias da elite local.

Essas experiências e narrativas não finalizaram nem com a morte dos persona- gens principais, nem com o fim deste período histórico. Com a injustiça da morte pelo sofrimento é aberto um espaço de continuidade, de permanente busca por uma redenção, com um presente/futuro em aberto, a dar-se para interpretação, assimilação e propagação por parte da memória social. Ou seja, a narrativa não encerra no que é contado, se abre para o mundo e para a relação com o espaço vivido cotidianamente.

\section{Referências}

ARRUDA, Tainá; SANJAD, Thais. Ornamentos de platibanda em edificações de Belém entre os séculos XIX e XX: inventário e conservação. An. mus. paul. vol.25 no.3 São Paulo, Sept./Dec. 2017.

BENEVOLO, Leonardo. História da cidade. 4.ed. São Paulo : Editora Perspectiva, 2005. CASTRO, Fábio. A Cidade Sebastiana: Era da borracha, Memória e Melancolia num Capital da Periferia da Modernidade. Belém: Edições do Autor, 2010.

CASTRO, F. F. de. Fenomenologia da comunicação em sua quotidianidade. InterCom: revista brasileira de ciencias da comunicacao, v. 36, p. 21-39, 2013.

CHAVES, Túlio. Isto não é para nós? Um estudo sobre a verticalização e modernidade em Belém entre as décadas de 1940 e 1950. Belém. 2011. f.142 Dissertação (Mestrado em História) - PPHSA/UFPA, Belém, 


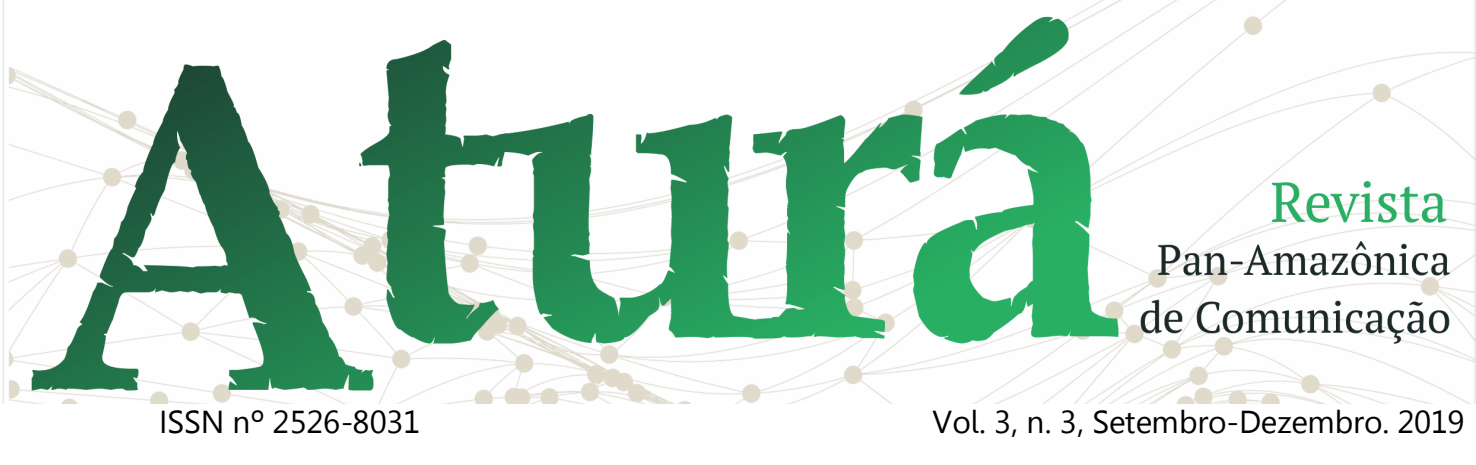

2011.

COIMBRA, Adriana Modesto. A cidade como narrativa: Francisco Bolonha e o papel da arquitetura e da engenharia no processo de modernização da cidade de Belém 1897 -1938. Campinas, SP. S/N, 2014.

COSTA, Francisco de Assis. Formação rural extrativista na Amazônia: os desafios do desenvolvimento capitalista (1720 - 1970). Belém: NAEA, 2012.

CORRÊA, Roberto Lobato. A periodização da rede urbana da Amazônia. Revista Brasileira de Geografia, v. 4, n. 3, p. 39-68, 1987. CANCELA, C. D. Casamento e relações familiares na economia da borracha: Belém (1870-1920). São Paulo. 2006. f. 343 Tese (Doutorado em História). FFLCH - USP, São Paulo, 2006.

CANCLINI, Néstor García. Imaginários culturais da cidade: conhecimento/espetáculo/ desconhecimento. In: COELHO, Teixeira (org.) A cultura pela cidade. São Paulo: Iluminuras: Itaú Cultural, 2008.

DERENJI, Jussara. Arquitetura Nortista: a presença italiana no início do século $\mathrm{XX}$. Manaus: SEC, 1998.

FURTADO, Celso. A formação econômica do Brasil. São Paulo: Companhia das Letras, 2007.

GODINHO, Emanuella da Silva. A invenção do centro histórico de Belém/PA. Belém. 2008. 381 f. Dissertação (não publicada) PPGAU /UFPA, Belém, 2019.

HALBWACHS, Maurice. A memória coletiva. São Paulo: Vértice, 1990.
HARVEY, David. A condição pós-moderna. São Paulo: Loyola, 1992.

HEIDEGGER, Martin. 2005. Ser e Tempo, 2 vols, 15a ed. Petrópolis: Vozes.

LEFEBVRE, Henry. O direito à cidade. São Paulo: Moraes, 1991.

LIMA, José Júlio; GUIMARÃES, Luciana. Janelas para o Rio: projetos de intervenção na orla urbana de Belém do Pará. In Vargas, Heliana C. e Castilho, Ana L. H. (Orgs.) Intervenções em Centros Urbanos: Objetivos, Estratégias e Resultados. São Paulo: Editora: Manole, 2a edição 2009

LOPES, Silvana. Investigações poéticas do terror. DIACRÍTICA, Ciências da Literatura, n. ${ }^{\circ}$ 23/3 (2009), 169-177

MARTINS, Analice; NICOLINI, Patrícia. Diálogo entre literatura e cinema: narrativas de terror - $\mathrm{O}$ estudo de estratégias narrativas para "ancorar o efeito do real" na linguagem literária e na linguagem cinematográfica. LITERARTES, n. 7, 2017.

MONTEIRO, Walcyr. Visagens e assombrações de Belém. 7. Ed. - Belém: Smith Editora - 2016.

MOTTA, Luiz Gonzaga. Análise crítica da narrativa. Brasília: Editora Universidade de Brasília, 2013.

NUNES, Benedito. O tempo na narrativa. São Paulo: Edições Loyola, 2013.

O LIBERAL. O sobrenatural pede carona; conheça histórias assombrosas de Belém. Disponível em:

https://www.oliberal.com/o-sobrenaturalpede-carona-conhe\%C3\%A7a- 


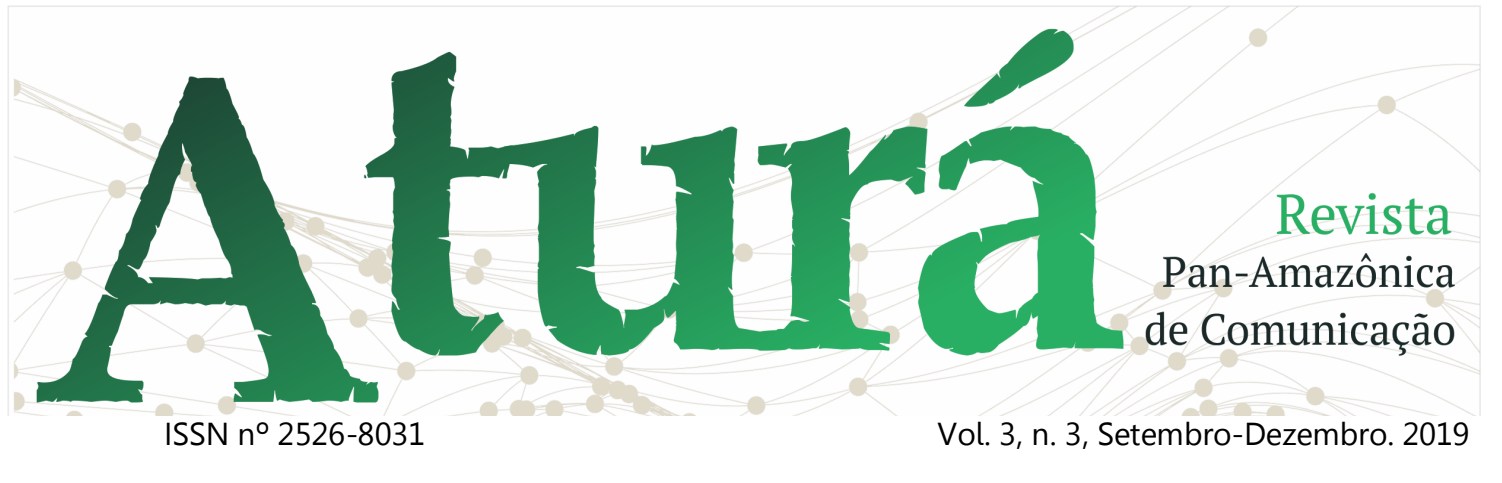

hist\%C3\%B3rias-assombrosas-debel\%C3\%A9m-1.123026>, acesso em 13 jun 2019.

RICOEUR, Paul. Tempo e Narrativa (Tomo I). Trad. Constança Marcondes Cesar. Campinas - SP: Papirus, 1994.

RIEGL, Alois. The Modern Cult of Monuments: Its Character and Its Origin. In: Oppositions 25: Monument/Monumentality, edited by Kurt Forster. New York: Rizzoli, Fall 1982.

SARGES, Maria de Nazaré. Belém: Riquezas produzindo a Belle-Époque (1870 - 1912). Belém: Paka-Tatu, 2000.

SENHORA MORTE. Belém Assombrada Bibi Costa. 2015. (3m24s). Disponível em: < https://www.youtube.com/watch?v=0Yt9PQ z5CQc>. Acesso em: 16 jun. 2019.

SENHORA MORTE. Belém Assombrada - As assombrações do Palacete Bolonha. 2016. (9m39s). Disponível em: < https://www.youtube.com/watch?v=OZP6r $n v-0 c w \& t=3 s>$. Acesso em: 11 jun. 2019.

SILVA, Helenice. "Rememoração"/comemoração: as utilizações sociais da memória. Rev. Bras. Hist. vol.22 no.44, São Paulo, 2002.

SOARES, Karol Gillet. As formas de morar na Belém da Belle-Époque (1870- 1910). Belém. 2008. 247 f. Dissertação (Mestrado em História Social da Amazônia) - Programa de Pós-Graduação em História Social da Amazônia/UFPA, Belém, 2008.

TOCANTINS, Leandro. Santa Maria de Belém do Grão-Pará. Rio de Janeiro: Editora Civilização Brasileira, 1963.

WEINSTEIN, B. A borracha na Amazônia: expansão e decadência (1850-1920). São Paulo: Hucitec;; Ed. Universidade de São Paulo, 1993. 